\title{
Women Mitigating Climate Change Impact Through Forest-based Activities
}

\author{
Lolita Pradhan*, S.P Singh and B.K.P Sinha
}

\begin{abstract}
The impact of climate change is disproportionately higher on women, the poor and socially disadvantaged groups. It impacts men and women differently, given their different roles and responsibilities at the household and community levels. In tribal societies women play a very important role as forest product gathers/collectors and users. They are the primary players in the collection, processing, and marketing of Non-Wood Forest Products (NWFPs) including food and fuel-related forest products. In this regard women bear the greatest burden and are most vulnerable to environmental degradations, and climate change. The forest ecosystems are also vulnerable to climate change and therefore the activities of forest inhabitants are likely to be adversely affected. There is a need for developing measures for adaptation to climate change for women folk. This can be possible through capacity building of women folk for adopting alternate source of livelihood, energy, and living conditions. Recognizing this, the state governments have initiated certain ecodevelopment programs which includes use of energy renewable measures like bioenergy, promoting alternative income-generating activities like home gardening, NWFPs processing etc., promotion of alternative energy sources like solar energy for rural electrification, use of environment friendly housing material, and watershed interventions with the objective of empowering women and ensuring their active participation to mitigate the impact of climate change in the long run.
\end{abstract}

Amity School of Natural Resource and Sustainable Development, Amity University, Noida, India

*Corresponding author; Email:

pradhanlolita2013@gmail.com
This paper attempts to analyse the ecodevelopment and capacity building program for tribal women in different states in and around the forest areas and analyse how these programs help in improvement of social, economic and institutional building in order to enable the tribal women folks to adapt to climate change.

\section{INTRODUCTION}

Forest resources are the safety net and source of living for the forest dependent communities which cannot be overlooked. As per National Report, FRI (2015), 1,47,127 forest fringe villages are dependent on the fringe forest area of $3,86,079 \mathrm{~km}^{2}$ for various product and services. These includes collection of edible fruits, flowers, tubers and roots and leaves for food and medicines; firewood for cooking (some also sell in the market); materials for agricultural implements, house construction and fencing; fodder (grass \& leaves) for livestock and grazing of livestock in forest; and collection of a range of marketable NTFPs and water. Forest ecosystem is closely linked to social systems. The forest fringe communities not just collect these forest products for their own consumption but also for commercial sale, which fetch them some income. The income from sale of the forest products constitutes $40-60 \%$ of their total income (Kumar et al, 2010; Sadashivappa et al, 2006).

Almost $85 \%$ of rural women around the world still derive their livelihoods from land and forestbased activities and any situation that causes deterioration of natural environment or that adversely affects their access and control over natural resources has a deep impact upon their lives. Women play a major role in NTFP and fuelwood collection. Their lives are intrinsically linked to natural resources such as land, water and forests, which are an integral part of an 
ecosystem that is becoming vulnerable. The effects of deterioration of natural environment on lives of women have been said to be multifold. In all rural households, it is the women who are responsible for collection of fuel wood for household purposes for cooking when forests recede, women have to walk farther thereby increasing the time and energy spent in getting fuel and fodder. Further, women also gather a diverse range of forest produce and participate as wage labour in forestry works. It is estimated that women's employment in forest-based enterprises is 571.85 million days of which $90 \%$ is in small scale enterprises using minor forest produce as raw material. The effects of deterioration of natural environment on lives of women have been said to be multi-fold. Since in all rural households, it is the women who are responsible for collection of fuel wood for household purposes for cooking when forests recede, women have to walk farther thereby increasing the time and energy spent in getting fuel and fodder.

Similarly, when the water table falls and there is scarcity of water needed for household purposes, women spend longer durations in completing household chores. Thus, any activity that alters women's access to natural resources-whether it is land, water or forests, has a direct effect on the level of social status, incomes and in turn their nutrition and health.

Similarly, when the water table falls and there is scarcity of water needed for household purposes, women spend longer durations in completing household chores. Any activity that alters women's access to natural resources-whether it is land, water or forests, has a direct effect on the level of social status, incomes and in turn their nutrition and health. Their limited adaptive capacities arise from prevailing social inequalities and ascribed social and economic roles that manifest itself in differences in property rights, access to information, lack of employment and inequal access to resources. Further, changes in the climate usually impact on sectors that are traditionally associated with women, such as
NTFP and fuelwood collection, paddy cultivation, cotton and tea plantations, and fishing. This means increased hardship for women which, in turn, impact the ecosystem - either positively or negatively.

The increased dependency of women has not only resulted in degradation of the forest resources but also lead to the drudgery of women. When economically empowered women raise healthier and better educated families, it increases their adaptive capacity" (also see Prowse et al., 2009; Solar, 2010; Beathge, 2011; Hill, 2011; OECD, 2011; Farming First, 2013; CARE International, 2013; Leichenko and Silva, 2014 all cited in Yadav and Lal, 2018: 12).

Despite women's vulnerabilities, women's knowledge and social practices could be used to build community resilience if women were included in adaptation and mitigation efforts. The paper "Role of women in mitigating climate change impact through forest-based activities" has attempted to analyse the eco-developmental activities (Eco-developmental activities provide alternative employment opportunities to individuals and families in order to reduce the forest dependent livelihoods to sustainable levels and to ensure people's active participation in protection of the forest resources. These are executed through eco-development committees) and capacity- building programs for tribal women in different states in and around the forest areas and analyse how these programs help in the improvement of social, economic and institutional building in order to enable the tribal women folk adaptation and mitigation to climate change.

\section{Conceptual frame work}

The National forest policy 1988 as well as the Scheduled Tribes and Other Traditional Forest Dwellers (Recognition of Forest Rights) Act, 2006 has emphasized and guaranteed them the right to use the forest resources for their subsistence and livelihood but due to lack of other livelihood means, ignorance and awareness the level of extraction of these resources have become 
unsustainable and exploitative which in turn can affect the general health of the forest and in the long run degrade the forest condition leading to increased emission of Carbon dioxide and thus result in climate change .

The changing climatic patterns in India, such as increased temperatures and changes in rainfall patterns, is predicted to have strong impacts on livelihood and biodiversity in the country. It is widely recognized that climate change has caused substantial impacts on forest ecosystems by causing shifts in vegetation types, phenology and the reproductive biology of various trees, shrubs and herbaceous plant species and altering the frequency intensity, duration, and timing of fire, drought, insect and pathogen outbreaks (Ravindranath et. al, 2006, Dale et al., 2001, Mukhopadhyay, 2009). Besides these scientific observations and predictions many communities have observed the changes in terms of phenology, reduction of quantity, and quality of produce.

The above impacts of climate change have further decreased the yield of the forest resources and resulted in exploitative harvest of the forest resources which in turn has resulted in impacts on the forest as listed in Table 1.

Scientist have claimed that unsustainable harvesting of the NTFPs can lead to conversion of dense forest to open forest, loss of Biodiversity, loss of endangered species. It can also lead to poor regeneration of Non-Timber Forest Products (NTFPs) species at heavily harvested sites (Koliyal 1997; Murali et al. 1996; Pant 2003), Invasion of weed leading to unproductive forests, soil erosion leading to infertility and desertification, high incidence of pest infestation and diseases and shrinking water resources and water shed. The cumulative effect of this can be higher Green House Gases (GHG) emission resulting in global warming.

Initiatives have been taken by forest department and different organization to develop alternatives so as to reduce the dependence of women on forest resources since women's participation is essential for sustainable development and climate change adaptation.

\begin{tabular}{|l|l|}
\hline Issues & Impacts \\
\hline Unsustainable fuelwood collection & $\begin{array}{l}\text { Destruction of regeneration of the forest tree } \\
\text { species }\end{array}$ \\
\hline Exploitative and destructive collection & Loss of bio-diversity \\
\hline $\begin{array}{l}\text { Removal of sapling and young trees instead of dead } \\
\text { and dying and Weed }\end{array}$ & Invasion of Weed. \\
\hline Excessive burning of the fuelwood & $\begin{array}{l}\text { Emission of GHG } \\
\text { Deforestation and Reduced potential for C } \\
\text { sequestration }\end{array}$ \\
\hline Exploitative harvest of NTFPs & Loss of biodiversity \\
\hline Damage to the NTFPs species & Poor regeneration of NTFPs \\
\hline Burning of forest floor - mahua, Aonla collection. & $\begin{array}{l}\text { Low productivity and C- sequestration } \\
\text { Forest Degradation and non-availability of NTFPs }\end{array}$ \\
\hline Overgrazing & No seed formation. \\
\hline Complete lopping of Young trees & Poor Regeneration and invasion of weed. \\
\hline Removal of young sapling. & Forest degradation. \\
\hline Uncontrolled Grazing and heavy lopping. & Reduction in biomass. \\
\hline
\end{tabular}

Table 1 Impact of climate change on forests 
The first step towards tackling the challenges of climate change is empowering women to safeguard the environment. When economically empowered women raise healthier and better educated families, it increases their adaptive capacity". Women utilise their experience and expertise to reduce the adverse impacts by adopting prudent strategies and are concerned about environmental issues. There is need to reduce the dependency of women on the natural resources and look out for better adaptive strategy so that they are able to cope up with the changing climate. There are, however, several ways of promoting women's economic participation while also counteracting climate change. The economic empowerment of women through climate mitigation and adaptation fosters economic growth and socioeconomic development, reduces poverty, keeps environmental problems in check, and increases the potential for adaptation, which is to the benefit of both women and men.

The paper tries to explore the alternative livelihoods adopted by different agencies so as to reduce the dependence of women on the forest resources so that they can cope up with the changing climate.

\section{MEHTODOLOGY}

The paper is based on the secondary literature survey of reports, journals articles on issues related to climate change and mitigation strategies practiced and preliminary survey of some of the practices adopted by women in the states of Madhya Pradesh and Chhattisgarh to combat the effect of climate change. Case study method has been used to understand the relationship and implications of climate change on women and the adaptation mechanism adopted by them to mitigate the problem. Social survey techniques and PRA tools were adopted in the tribal dominated districts of Madhya Pradesh like Betul, Raisen and Dhamtari district of Chhattisgarh.

In order to study the dependency of women on natural resources and assess the impact of climate change - Focus group discussion and PRA tools were used. Based on the inputs of the PRA tools and social survey the discussions and interviews were conducted with the forest department and the women member involved. Besides the secondary literature was also consulted for the same.

\section{RESULT AND DISCUSSION}

Women and its dependence on natural
resources

In the studied districts the tribal women are actually dependent on the natural resources for their own and their family's survival. They are given the task of securing water, food and fuel for cooking and other purposes. They are the collectors, conservators, protectors and managers of all natural and rural resources and play significant roles in catering the domestic requirement of their homes.

The discussion with the tribal women revealed that more than $84 \%$ of women are involved in agricultural activities, and as a result they have become the greatest victims of climate change impacts. Women also play a very significant role in livestock management, whether of small ruminants (goats, sheep, pigs and chicken) or milch cattle. Women have a packed work schedule and are also involved into wage-work to supplement household earning; taking care of vegetable cultivation in their marginal farms or homesteads; selling and trading in various forest products, NTFPs and vegetables collected in the weekly markets. But it is collection of NTFPs that has been the backbone of the tribal women's livelihoods, especially during non-agricultural season.

The discussion with the Gond tribal women of Betul and Hoshangabad districts of Madhya Pradesh revealed that NTFPs acted as safety net for the tribal community during the lean agricultural months. Women were mostly involved in collection of NTFPs like mahua, tendu, Achar and aonla. The decline in the yield of the NTFPs resulted in the reduction in their income. On discussion with the women folks about the 
harvesting techniques adopted by them for extracting these NTFPs it was realized that $80 \%$ of them resorted to exploitative harvesting practices like burning of forest floor for collection of mahua fruits (so that it is easily visible), lopping and cutting the branches of aonla and achar trees for collection of their fruits, uprooting the plants etc. Besides NTFP collection fuelwood collection was another important activity in which the women in which women were actively involved in. During the discussion with the tribal women of Raisen and Betul districts of Madhya Pradesh it was found that they travelled long distance 4-6 Km daily and spend almost 6-8 hrs in search of fuelwood and NTFPs. Everyday women collect about one headload of fuelwood which was about $40-50 \mathrm{~kg}$, which is partially consumed and partially sold @20-30 per head-load. The women even complained that due to the shortage of dry fuelwood they had to sometimes cut the live green trees which in turn has further deteriorated the forest condition and affected the upcoming regeneration resulting in the decline of quantity and quality of the NTFPs.

\section{Fuelwood collection a cause of forest degradation in India}

More than $67 \%$ of rural households in India still depend on firewood or wood chips for cooking.

Head load of fuel-wood: $40 \mathrm{~kg}$ approx.

Consumption of fuel-wood/ family/meal: $10 \mathrm{~kg}$ during summer \& 12-15 kg during winter.

Visit to Forests: 20 days a month $=240$ days $/$ year

Removal of fuel-wood/ family / year:

Table 2: Source: Ministry of Statistics, Government of India
Impact of climate change on women

A discussion with tribal women of both the states revealed that $80 \%$ of the women agreed there is a considerable change in the climatic condition which has greatly affected yield from the forest as well as agricultural fields. Rainfall are now erratic and there are long dry spells which in turn has affected the quality and quantity of the NTFPs like Aonla, Achar, Bahera etc which has declined drastically. They have to spend more hours now in search of these NTFPs. The availability of water and fuelwood has also declined. Now they have to walk longer distances and spend more hours in search of it. It was very clearly evident that climate change had a significant impact on activities involving procuring of household water, food, and fuel. Eighty percent of women complained that now women and girls have to walk farther than before and thus spend more of their time collecting water and fuel. Girls may have to drop out of school to help their mothers with these tasks, continuing the cycle of poverty and gender inequality. The rate of migration of the women folks have also increased as a result of decline of livelihood opportunities. Changing climate has also affects the health of crops and livestock, and women, who are often responsible for producing the food eaten at home, have work harder to compensate for less food.

Discussion with the tribal women revealed that climate change can affect the women several ways (Table 3).

Initiatives taken for increasing the adaptability and mitigating the impact of climate change on women

Climate Change Mitigation refers to efforts to reduce or prevent emission of greenhouse gases. In other words, "Any human intervention designed to reduce emission of GHG at source or enhance sinks". The strategies adopted by the forest department and different organizations to increase the adaptability and mitigating the impact of climate change on women is summarized. 


\begin{tabular}{|l|l|}
\hline Issues & \multicolumn{1}{|l|}{ Impacts on women } \\
\hline $\begin{array}{l}\text { Collection of natural resources, food, } \\
\text { watel wood }\end{array}$ & $\begin{array}{l}\text { Increased household work burden and time spent on gathering } \\
\text { water, food and firewood (sometimes leading to lower school } \\
\text { enrollment rates, decreased literacy rates, or early marriage) } \\
\text { Increased hunger and calorie reduction for women } \\
\text { Exposure to contaminated water sources }\end{array}$ \\
\hline Health & $\begin{array}{l}\text { - Heat-related illness } \\
\text { Malnutrition }\end{array}$ \\
\hline Migration and displacement & $\begin{array}{l}\text { - Reduced availability of resources lead to forced migration could } \\
\text { magnify women's vulnerability, lack of access to resources and } \\
\text { livelihood options }\end{array}$ \\
\hline
\end{tabular}

Table 3: Impact of Climate Change in Women Source: Primary Survey, Raisen and Betul district of Madhya Pradesh, India 2013-2014

\section{* Spends 5-6 hours/day. Cannot earn wages on those days, she goes to collect fuel-wood. Carry head load $40 \mathrm{~kg}$ weight for 4-5 km.}

\section{Empowerment of women}

Acknowledging the role of women as resource users and managers the National Forest policy 1988 emphasize equal participation of women in forest management and planning which was later on reemphasized in Joint Forest Management (JFM) revised guidelines of 2002 which clearly mentioned about $50 \%$ representation of women in the JFM committees as well as JFMC meetings. At least $33 \%$ of the membership in the JFM Executive Committee/Management Committee should be filled from amongst the women members. The quorum for holding meeting of such Executive/Management Committee should be one-third of women executive members and one of the posts of office bearer i.e. President/Vice-President/Secretary should be filled by a woman member of the Committee. In the last two decades in accordance with the Forest Policies and planning the women's role has been considered as highly valued in the decisionmaking process starting from planning, implementation, monitoring and evaluation in the activities of Joint Forest Management or Forest Development. The roles and responsibilities of them have been found essential in forestry activities, especially in NTFPs.

Many cases of processing, value addition and enterprise development empowering the tribal

women have been initiated by the forest departments to provide a livelihood opportunity to them and reduce their dependency on the forest resource. Women have been engaged in plantation activity as well as other Entry Point Activities. Under this program many trainings and capacity building programs have been conducted by the Forest Department for enterprise development so as to make the women members self-sufficient and empower them economically, politically, socially and psychologically. The Forest department through various provisions, initiatives and programs tried to create a conducive atmosphere for women in forest management so that they become self-sufficient and less dependent on the forest resources for livelihood and are empowered to take decisions in JFM activities. The development interventions executed under the JFM activity have been undertaken to empower the women members economically and socially (Pradhan, 2017). 
Sustainable harvesting methods for NTFPs enhancing natural aided regeneration of forests.

Women need to be sensitized about the impacts of unsustainable harvesting and also be involved in regeneration and plantation of NTFP based species. Training and capacity building of the women for sustainable harvesting is very much essential. In the states of Madhya Pradesh, West Bengal, Orissa, Jharkhand, Maharashtra and many other tribal dominated areas training and, village level workshops have been conducted by forest department and many other organizations. Indian council for Forestry Research and Education (ICFRE) Institutes have developed various practices of sustainable harvesting of NTFPs in-order to avoid deforestation and degradation. National Medicinal Plant Board (NMPB) has developed collection and cultivation manual of the NTFPs \& medicinal plants. In this regard programs have also been undertaken by various agencies including the NonGovernmental Organizations (NGOs).

Value addition to forest produce and developing proper market chain

Initiatives have been taken in various parts of the country to increase the value of the NTFPs through primary and secondary processing. Herbal processing centres have been set up in many parts of Madhya Pradesh, Chhattisgarh, Orissa, Andhra Pradesh and tribal dominated states where in the women members who form Self Help Groups (SHGs) are involved in processing of the NTFPs into different forms (Forest Governance Learning Group, 2008). Chhattisgarh Minor Forest Produce Federation had developed a comprehensive programme focusing on organized production, collection, processing and marketing through community based institutional and marketing set-up in the form of "Sanjeevani" (Gautam and Sharma, n.d). This Federation has prioritized species based on area, established community-based small processing units and handed these over to local SHGs headed by women Mostly these centres are involved in processing of Bauhinia Vahlii (mahul leaf), honey, Embilica Officinalis (Amla), herbal products, oil seeds and tamarind. For standardization of the processing techniques of different herbal products, support has been taken from institutions like Central Food Training and Research Institute (CFTRI), Mysore; Central Drug Research Institute (CDRI); Central Lac Research Institute, Ranchi; Central Institute of Medicinal and Aromatic Plants (CIMAP), Lucknow. In the NTFP Processing centre established in Duguli in which women members process NTFP like Embilica Officinalis (Amla), Terminalia Belerica (Bahera), Terminalia chebula (Harra) into processed herbal products like Shatawari, Safed Musali, Ashgandh, Trikhur powder etc., and have become part of the Sanjeevani network. Similar initiatives have also been taken in the state of Madhya Pradesh Forest department.

Initiatives have also been taken by the forest department to regularize the NTFP marketing. As in case of Chhattisgarh state where the processed NTFP products are sold through Sanjavani outlets and NTFP marts these herbal products are sold under the brand name of 'Chhattisgarh Herbals' at retail rates. Similar initiatives have also been taken in the state of Madhya Pradesh in which the processed NTFPs are marketed through the brand name of Vindhya Herbals. These attempts have increased the income of various women folk.

\section{Enhancement of climate change adaptability of women}

The capacity building programme under ecodevelopment activity has been under taken to enhance climate change adaptability of women. The capacity building program for adopting energy saving devices (improved cook stoves, solar light, cookers) is most significant as an efficient utilization of alternate energy source can reduce the demand of fuelwood which in turn helps in reducing the adverse impact of forest ecosystem. Forest department of Madhya Pradesh and Chhattisgarh have adopted initiatives like distribution of smokeless chullahs, LPG gas cylinders in subsidized rates in forest fringe villages. Organizations like Centre for Environment and Energy initiated an innovative process to establish and integrate efforts at the community level into the climate change 
mitigation process through adoption of low carbon products in the state of Karnataka and Tamil Nadu were women where nurtured into micro entrepreneurs and were directly involved in marketing solar products and in cooking stove. During this project period, about 100 fuel efficient cook stoves and 500 solar products were sold by these women thus benefiting about 11,000 people through access to low carbon products. This initiative has demonstrated potential income generation of about Rs 2000 - 3000 per woman per month on a flexible / part time basis with scope a to go as high as Rs 5000 depending on products. These trained women are creating awareness on low carbon technologies/ products in their communities; they share their own experience with the community and motivate the community to switch to a low carbon lifestyle. They have reached more than 11000 people in about a year, creating awareness on low carbon products (http://tide-india.org/low-carbontechnology/). This has been a major incomegenerating opportunity for the women entrepreneurs who also played an important role in knowledge dissemination about mitigation of $\mathrm{CO}_{2}$ through adoption of low carbon products and technologies. A group of women have been trained further in assembly and repairs of solar products. Also, five of the women have opened an eco-store to market low carbon products.

\section{Forest protection and afforestation}

Forest department in the states of Madhya Pradesh, Chhattisgarh, Andhra Pradesh have initiated measures to involve women in plantation and afforestation program. They have even involved themselves in nursery raising. In some states like Orissa women even patrol and to protect it from grazing, unsustainable NTFP harvesting and fuelwood collection. This has helped in regeneration of degraded forests and more C-sequestration.

The case study from the state of Uttarakhand has been evaluated. In this study women's group of Kausani village of Uttarakhand had launched a movement to save the Kosi biver by planting broad-leafed trees around it. The women not only treated catchment areas to ensure proper drainage but also prevented grazing by livestock. So, when large swathes of rural Uttarakhand in India were facing severe water crisis in the summer of 2016, the situation in Kausani was under control. The way women folks played an important role in the protection of water resources as well as sensitized other communities about the importance of catchment treatment activities remains a challenge (Chakraborti, 2016)

Enterprise Development as alternative source of livelihood

Importance is being given to income generating activities wherein women are being mobilized through training and capacity building in income generating activities such as poultry, apiculture, mushroom, papermaking, floriculture, aromatic and medicinal plant cultivation and vegetative cultivation, forest's handicrafts to reduce dependency on forests

The author studied the paper mache making activities in the state of Madhya Pradesh. In village Bamnai situated in Raisen district of Madhya Pradesh the erratic rainfall resulted in the decline of the forest resources as well as agricultural productivity which forced the tribal women to migrate to other states in search of work, which further added to the drudgery of women. An innovative income generating activity of paper mache craft making was adopted by the tribal women under the guidance of the forest department who not only gave them training and raw materials but also provided a buy-back arrangement of the products prepared by them. The forest department imparted training for this activity through some NGOs/institutes. Women made toys and handicrafts from paper mesh/waste paper which was provided by the forest department, these toys were then sold at herbal mela (van melas) organized by the forest department, which are held regularly at different places of the state. They were also exhibited in Delabadi Ecotourism centre. The women members earned income ranging from 3000-5000 as per their sale which was much more than what they earned by selling NTFPs and Fuelwood. 
Besides their daily chores and other activities, they do this activity in their own convenient time sitting at home. They make the materials as per the demand and supply it either to the forest department or to individuals. This activity has helped in increasing the income of the women members and reduced their dependency on forest resources to a great extent. This can be taken as an example of good adaptability.

Convergence of indigenous knowledge and government schemes in Sericulture

Another innovative approach was adopted in Guvasen village of Betul under the UNDP-GEF project in which forest department initiated an income generating activity for the women Joint Forest Management Committee (JFMC) members of the village wherein the women were involved in extracting threads from the silk cocoons. Forest department provided them with the infrastructure and sericulture department provided training to undertake the work. The sericulture department supplied cocoons to the women members and purchased the silk thread from them. The payment was based on the grades of thread extracted. The women members involved in this activity earned monthly income of Rs 4000-6000. This activity was done in collaboration with the sericulture department of Madhya Pradesh Govt. In a single day woman weave about $100-200 \mathrm{gm}$ of cocoons. The women who were involved in this activity were very happy and satisfied with the work and the income earned. This greatly reduced their dependency on forest resources and migration also declined considerably. Women members had become more confident and feel more secured and independent (Debnath and Pradhan, 2015.)

\section{Changing cropping pattern and conservation of natural resources}

The analysis of case study of Rajasthan revealed that under the CGIAR Research Program on Dryland Systems, women members of Derasar village in Rajasthan have pioneered the use of innovations such as the use of improved crop varieties - including pearl millet and other crops suited to the region, the planting of fruit trees to provide nutrition and income, constructing embankments to capture rainfall and prevent runoff and soil erosion, and the planting of grasses and fodder trees to provide fodder for cattle. This helped them to combat the acute water scarcity in the Thar desert and helped the women farmers in adopting new farming methods that have helped them in dealing with the impacts of climate changes in the drylands thereby overcome poverty. This program also helped in developing institutional arrangements that have been implemented to enable communities to manage common property resources such as common grazing lands in a better way. They have also formed women's selfhelp groups to weigh and market livestock for higher income. To make this happen, these women farmers worked with a local community organisation, the Gramin Vikas Vigyan Samiti (the village development knowledge committee) and received scientific expertise from the International Crops Research Institute for the Semi-Arid Tropics (ICRISAT) (Akbari, 2015).

\section{Initiatives of home gardening in West Bengal}

Over the past years, Global Greengrants Fund has supported SHG Maa Durga through a grant to the Development Research Communication and Services Centre. This organization is helping 150 women farmers, including members of Maa Durga of Sunderban, to strengthen their food security and livelihoods, and to raise awareness about climate changes. Maa Durga women are also learning sustainable agriculture practices to reduce their dependency on expensive and harmful chemicals and pesticides, and they are planting kitchen gardens with diverse varieties of nutritious food crops. Women are also being taught about vermicomposting, preparing natural pesticides and fertilizers using cow dung, neem leaves, and other natural materials. They are now growing more than 13 varieties of vegetables, greens, and tubers in their small home garden.

Apart from this Women from the Maa Durga also organize rally in their community to raise awareness about climate change and to promote sustainable agriculture. They were also part of a camp to raise awareness about the harmful effect 
of chemical fertilizers and pesticides. Local women's groups also plan to advocate for their rights and government entitlements by participation in the gram sabha-a meeting of voting adults, who are part of the local selfgoverning unit called the panchayat. Women in nearby villages learnt to increase their food security by setting up seed banks, practicing sustainable agriculture, and adding livestock, like chickens, to their homesteads. These seed banks are small repositories of native, saline-, and floodresistant crops. They have taken a step in the long process of experimentation to adapt to a changing climate in a region where floods are expected to get worse and more frequent. They have been encouraged to install bio-digester plant for generating cooking fuel from farm waste, including livestock manure, which is judiciously recycled to provide nutrients to crops. Women farmers now have proved that they are crucial drivers of change and can persevere in the face of vulnerabilities (Chitnis, 2013).

\section{CONCLUSION}

A number of case studies have revealed that tribal women are more affected and are vulnerable to climate change and therefore there is a need to support various programmes which can enhance their adaptability to mitigate the adverse impact of climate change. The most significant programme is the eco-development program headed by the government. Under this program the women folk are able to adopt alternative source of livelihood and decrease their dependency on the forest resources. In order to develop any mitigation strategy for climate change women's needs should be taken into account by working directly with them and they should be empowered to take charge of their lives and reduce the vulnerability of the communities. Women are expert resource users as well as managers and their knowledge and skills should be used for developing strategy for mitigating climate change.

\section{REFERENCES}

Agarwal, 1986, 'Cod Hearth \& Barren Slopes: The wood fuel Crisis in the Third Word', New Delhi, Allied Publishers Pvt Ltd.
Akbari, S (2015, November 26). Rajasthan Women farmers beat climate change global warming. Times of India. Retrieved from https://timesofindia.indiatimes.com.

Kumar, B., Patil, L.B, Basavaraja, B.L, Mundinamani H., Mahajanashetty S.M, S.B, Megeri, S.N 2011, 'Participation Behaviour of Indigenous People in NonTimber Forest Products Extract in western ghats forests', Karnataka Journal of Agriculture, Science, Vol. 24, no.2, pp.170-172.

Chitnis, R 2013, 'How women in rural India are adopting to changing climate change. Newsletter of Global green Grand Fund. Retrieved from https://www.greengrants.org/2013/06/24/how-

women-in-rural-india-are-adapting-to-a-changingclimate/

Dale V. H. 2001, 'Climate change and forest disturbances', BioScience, Vol. 51, pp.723-734.

Debnath, D. and Pradhan, L. Empowerment of Tribal Women through Joint Forest management. In S.N Choudhary edited book Tribal Women: Yesterday, Today and Tomorrow (pp183-2014). Jaipur, India Rawat Publication.

Forest Governace Learning Group, 2008, 'Non-Timber Forest Products and Forest Governance', Synthesis Report. Retrieved from http://pubs.iied.org/pdfs/G02293.pdf.

FAO, 1993, Forest resources assessment 1990 tropical countries. FAO Forestry Paper 112, Rome Italy.

Forest Survey of India, Dehradun 2015, State of Forest Report.

Gautam and Sharma (n.d). Livelihood Promotion through Non-Timber Forest Produce: A Case of Chhattisgarh State. Retrieved from http://ilrtindia.org/downloads/rajendra\%20S\%20case \%202-2_11.pdf

Houghton, R. A. 1996, 'Terrestrial sources and sinks of carbon inferred from terrestrial data. Tellus, Vol. 48, pp.420-43.

Koliyal, A. 1997, 'Extraction of Non-Timber Forest Produce from Selected Tree Species in Betul Forest Division and its Impact on the Population Structure of these Species', unpublished M.Sc. thesis. Dehradun: Wildlife Institute of India.

Pradhan, L., Kandya, A.K and Bhattacharya, P. 2017, 'Livelihoods Interventions under Joint Forest Management. In Bhattacharya, P. and Kandya, A.K (Eds.), Sustainable Forestry: Emerging Challenges (pp.115-128). New Delhi, I.K international publishing House.

Mukhopadhyay, D. 2009, 'Impact of climate change on forest ecosystem and forest fire in India', Earth and Environmental Science, Vol. 6, no.3, pp.20-27. 
Murali, K.S., R.U. Shaankar, U. Shankar, K.N. Ganeshaiah and K.S. Bawa 1996 'Extraction of NonTimber Forest Produce in the Forests of Biligiri Rangan Hills, India, 2: Impact of NTFP Extraction on Regeneration, Population Structure and Species Composition', Economic Botany, Vol. 50, pp.252-269.

Pant, A. 2003, 'Ecological Analysis of the Satpura Conservation Area Landscape through Stratified Field Sampling and Remotely Sensed Data', Proceedings of Map 2003. New Delhi: Department of Science and Technology. Retrieved from http://www.gisdevelopment.net/application/environ ment/ conservation/mi0321.htm

Ravindranath, N.H, Joshi, N.V., Sukumar, R. and Saxena, A. 2006, 'Impact of climate change on forest in India', Current Science, Vol. 90, no.3, pp.354-361.

Sadashivappa, P., Suryaprakash, S. and Vijaya Krishna, V. 2006, 'Participation Behavior of Indigenous People in Non-Timber Forest Products Extraction and Marketing in the Dry Deciduous Forests of South India', Conference on International Agricultural Research for Development, Tropentag University of Bonn, October 11-13.

Tan, K., Pio, S., Peng, C. and Fang, J. 2007, 'Satellite based estimation of biomass carbon stocks for northeast China's forest between 1982 and 1999', Forest Ecology and Management, Vol. 240, pp.114121.

UNDP 2011, 'Overview of linkages between gender and climate change. Policy brief on gender and cliamte change Asia and Pacific', Retrived from http://www.undp.org/content/dam/undp/library/gen der/Gender\%20and\%20Environment/PB1-AP-

Overview-Gender-and-climate-change.pdf

Zhou, L., Dai, L., Wang, S., Huang, X., Wang X, et al. 2011, 'Changes in carbon density for three old-growth forests on Changbai Mountain, Northeast China: 1981-2010', Annals of Forest Science, Vol. 68, pp.953958. 